\title{
One or several categories? The Old Church Slavonic nq-verbs and linguistic profiling
}

Tore Nesset, University of Tromsø, Norway

\begin{abstract}
In this article, I investigate the Old Church Slavonic verbs with the $-n q$ suffix, both verbs that keep the nasal suffix throughout the paradigm (e.g. plinoti 'spit') and verbs that display $-\varnothing$ in the past tense (e.g. pogybnoti 'perish'). Do these verbs constitute one or more linguistic categories? Having compiled a complete database of relevant verbs in Old Church Slavonic, I argue for a compromise, according to which all no-verbs belong to the same category network, but display different centers of gravity (prototypes) within this network. The network hypothesis is corroborated by detailed statistical analysis (called "linguistic profiling"), which takes into account semantic as well as formal properties of the verbs in question.
\end{abstract}

Аннотация: Данная статья посвящена старославянским глаголам с суффиксом -no. В статье рассматриваются и глаголы, сохраняющие суффикс во всей парадигме (напр., plinoti), и глаголы, в которых суффикс $n g$ в формах прошедшего времени чередуется с нулевым суффиксом (напр., pogybnoti). Образуют ли эти глаголы одну или несколько лингвистических категорий? Для ответа на этот вопрос была составлена исчерпывающая база данных, включающая все старославянские глаголы на -no. Анализ базы данных позволяет утверждать, что все глаголы на -nq принадлежат к одной категориальной сети, но имеют разные центры тяжести (прототипы) внутри этой сети. Сетевая гипотеза находит подтверждение в подробном статистическом анализе (“лингвистическое профилирование"), при котором учитываются и семантические, и формальные характеристики соответствующих глаголов.

Key words: Old Church Slavonic, Nasal verbs, suffix $-n q$, linguistic profiling, statistical analysis of language data

Acknowledgement: I am indebted to Henning Andersen, Stephen Dickey, Laura Janda and audiences in Oslo and Moscow for comments on earlier versions of this study. I would also like to thank my colleagues in the CLEAR research group (Cognitive Linguistics: Empirical Approaches to Russian) at the University of Tromsø for valuable input. This article was written while I was a fellow at the Centre for Advanced Study (CAS) at the Norwegian Academy of Science and Letters in Oslo. The support from CAS is gratefully acknowledged. 


\section{Introduction and overview}

Characteristic of the Slavic languages is the existence of two different categories of verbs with nasal suffixes. For instance, in Contemporary Standard Russian there is one productive category of verbs like maxnut' 'wave once', which typically have semelfactive meaning and keep the nasal suffix throughout the past tense forms (e.g. maxnul), and an unproductive category of verbs like gasnut' 'go out (about light)' which typically have inchoative meaning and display variation between $-n u$ and $-\varnothing$ in the past tense forms (gasnul vs. gas 'went out'). Plungian $(2000,218)$ refers to the coexistence of the two categories of verbs with nasal suffix as "a general Slavic word-formation riddle" ("obščeslavjanskaja slovoobrazovatel'naja zagadka").

The purpose of the present article is to investigate this riddle by addressing the situation in Old Church Slavonic (OCS) - the oldest Slavic sources available. Did the relevant verbs in OCS constitute one unified or two or more distinct categories? I will argue that neither the "one-category hypothesis" nor the "multi-category hypothesis" offers a realistic picture of the situation in OCS. Instead I suggest a "network hypothesis", according to which all OCS nasal verbs form a network of related subcategories, but have different centers of gravity (prototypes) within this network. The network hypothesis captures the similarities and differences attested in the verbs in question. I explore semantic properties (agentivity and embodiment), as well as formal properties (prefixation and shape of the root). As for semantics, the verbs that consistently keep the nasal suffix throughout the paradigm (henceforth "nasal verbs") show a high degree of agentivity and embodiment, while verbs that do not keep the nasal suffix in the past tense forms ("Ø-verbs") are typically low on agentivity and embodiment. With regard to formal properties, it will be shown that unprefixed verbs are less frequent among $\emptyset$-verbs and that different root-shapes are characteristic of nasal verbs and $\emptyset$-verbs. Both for meaning and form, however, we are dealing not with categorical differences, but rather statistical tendencies that can be accommodated in a network of related and partly overlapping subcategories.

In order to investigate the category structure of the OCS nasal verbs I employ empirical methods developed within the framework of cognitive linguistics, namely grammatical profiling and radial category profiling. After an overview of the relevant hypotheses and data in sections 2-3, grammatical profiling is discussed in section 4. Section 5 explores semantic properties in terms of radial category profiling, while formal properties are considered in sections 6 and 7 . Section 8 summarizes the argument.

\section{Hypotheses and data}

Let us start by making three hypotheses explicit. In view of the situation in Contemporary Standard Russian and other modern Slavic languages (cf. Schuyt 1990 for overview), one may expect OCS verbs with the suffix -no to constitute two or more different categories: 
(1) The multicategory hypothesis: The OCS no-verbs constitute two or more categories with clear-cut boundaries where the members of one category display systematically different behavior from the members of the other categories.

In favor of the multi-category hypothesis is the fact that many researchers believe that the $n \varphi$-verbs developed from different Indo-European verb classes (cf. Schuyt 1990, 265ff. and Gorbachov 2007, $47 \mathrm{ff}$. for detailed discussion). However, the origin of the OCS no-verbs is uncertain, and even if they did develop from distinct categories, these categories may have merged in Common Slavic (see Dickey forthcoming for discussion). As an alternative to the multicategory hypothesis in (1), consider (2):

(2) The one-category hypothesis: The OCS $n q$-verbs constitute one category whose members show uniform behavior.

In the scholarly literature on OCS verbs it is rarely made explicit what it means to constitute a linguistic category. However, traditionally linguistic categories are considered to be of the so-called Aristotelian type, i.e. unstructured sets of members that all share the same necessary and sufficient properties (see Taylor 2003 for critical discussion). An alternative conception is the so-called radial category (Lakoff 1987), i.e. a network of related subcategories organized around one or more prototypes. The radial category enables us to formulate a compromise between (1) and (2):

(3) The network hypothesis: The OCS $n q$-verbs form a network of related and partly overlapping subcategories organized around different prototypes.

To the best of my knowledge, the network hypothesis has not been made explicit in the scholarly literature on $n q$-verbs in OCS. However, Dickey's (forthcoming) proposal that "verbs suffixed in -no- were two manifestations of a single semantic category" is compatible with the network hypothesis in (3).

In order to test the hypotheses empirically it was necessary to create a database consisting of all inflected forms of all $n q$-verbs in OCS. This was done in two steps. First, a complete list of OCS no-verbs was culled from Sadnik and Aitzetmüller (1955, 192-193). Then all these verbs were checked against Aitzetmüller (1977), and a complete list of inflected forms was entered manually. The resulting database consists of 1331 verb forms from the following sources (total number of attested examples in each manuscript in parentheses; for ease of cross-reference the designations of the sources are the same as those used by Aitzetmüller 1977, vi):

(4) Assemanianus (128), Blätter des Undol'skij (7), Blätter von Chilandar (1), Clozianus (27), Euchologium Sinaiticum (83), Fragmentum liturgiarii sinaiticum (2), Kiever Blätter (3), Makedonisch glagolitisches Blatt (1), Makedonisch kyrillisches Blatt (1), Marianus (187), Novgoroder Blätter (7), Ochrider Evangelienfragment (1), Psalmenfragment von Sluck (8), Psalterium Sinaiticum (188), Samuel-Inschrift (1), Savvina kniga (81), Suprasliensis (432), Zographensis (172), Zographos-Blätter (1). 
At this point one must ask whether data from such a variety of sources represent a linguistic system that is homogeneous enough to lend itself to linguistic analysis. OCS is traditionally defined as the language attested in Slavic manuscripts from before 1100 AD (cf. e.g. Diels 1963, 1 and Lunt 2001, 1). However, these sources are quite diverse both geographically and temporally, and $1100 \mathrm{AD}$ is to some extent an artificial "end-point". Moreover, the manuscripts that have come down to us may have been copied several times, and each manuscript therefore may incorporate linguistic features from different diachronic layers and regional dialects. In other words, OCS is not a language of a speech community at a point in history, but rather the name of a corpus of texts. How linguistically homogeneous or diverse this text corpus is, is an empirical question. Since a broad discussion of a wide range of linguistic variables is beyond the scope of the present study, let us focus on the $-n q /-\emptyset$ variation. Table 1 provides an overview of the situation in the seven manuscripts with the highest numbers of attestations of no-verbs. Included in the table are numbers for the past tense forms where $-n q /-\emptyset$ variation is possible: aorist, past active participle, resultative participle ("l-participle") and past passive participle. The leftmost column gives the names of the relevant manuscripts. The next two columns offer the raw numbers of past tense forms with a nasal suffix and a $-\varnothing$ suffix, respectively. The two rightmost columns provide total numbers for each source as well as the percentage of forms with a nasal suffix for each manuscript. As shown in the table, we have a total of 766 attested examples, and the percentages of forms with a nasal suffix vary between $35 \%$ and $53 \%$. Statistical analysis shows that the differences are on the borderline between what is normally considered statistically insignificant and significant, and that the effect size is quite small. ${ }^{i}$ Although there are differences among the manuscripts, we cannot be sure that they are not due to chance, and even if they are not due to chance, the manuscript is a factor that has very limited impact on the choice between the $-n \varphi$ and $-\emptyset$ suffix. In other words, despite the observed variation the situation in general is relatively homogeneous, and further analysis of the OCS $n q$-verbs as one body of data seems feasible.

\begin{tabular}{lrrrr} 
& \# nasal & $\# \varnothing$ & \# total & \% nasal \\
\hline Assemanianus & 41 & 36 & 77 & 53 \\
Euchologium sinaiticum & 12 & 22 & 34 & 35 \\
Marianus & 54 & 66 & 120 & 45 \\
Psalterium sinaiticum & 39 & 55 & 94 & 41 \\
Savvina kniga & 29 & 26 & 55 & 53 \\
Suprasliensis & 105 & 179 & 284 & 37 \\
Zographensis & 50 & 52 & 102 & 49 \\
Total & 330 & 436 & 766 & 43
\end{tabular}

Table 1: $-n g /-\emptyset$ variation in various sources (all verbs)

\section{Classification of the verbs}

In order to test the hypotheses from section 2 it is necessary to classify the verbs, which fall into four groups with regard to $-n q /-\emptyset$ variation. First, there are " $\emptyset$ verbs", i.e. verbs that consistently lack the $-n g$ suffix in the past tense forms. An example is pogybnoti 'perish', which has aorist forms like pogybe in (5), past active participles like pogybšaago in (6) and resultative participles like pogyblz in (7), but no corresponding forms with $-n Q .{ }^{\text {ii }}$ 
(5) I niktože otъ nixъ ne pogybe.

'And none of them is lost.' (Marianus 385,26: John 17.12)

(6) Zaxariję pogybšaago meždju oltaremь i xramomъ.

'Zechariah, who perished between the altar and the sanctuary.' (Marianus 251,24: Luke 11.51)

(7) Pogyblı be i obrete sę.

'He was lost and has been found.' (Savvina kniga 68v9: Luke 15.24)

There are also "nasal verbs" - verbs that consistently display the nasal suffix in the relevant past tense forms. A case in point is pomęnoti 'remember', which keeps the nasal suffix, as illustrated in (8)-(10).

(8) I pomęno Petrъ glъ isvъ iže reče emu.

'And Peter remembered the word which Jesus had said.' (Assemanianus 92a18: Matthew 26.75)

(9) Plakaxomъ sę pomęnǫvъše Sionъ.

'We cried having remembered Sion.' (Suprasliensis 418,22)

(10) 0 kako Luka vısь straxъ Kleopovъ pomęnǫlъ.

'Oh how did L remember K's fear!' (Suprasliensis 477,19)

A third group of verbs display past tense forms both with and without the $-n q$ suffix. For convenience, I will refer to verbs of this type as "vacillating verbs". By way of example, consider the $3 \mathrm{pl}$ aorists užasnošę sę and užaso sę of užasnoti sę 'be astonished':

(11) I užasnǫšę sę užasomb veliemb.

'And they were astonished with a great astonishment.' (Marianus 134,18: Mark 5.42)

(12) I užas@ sę vbsi.

'And they were all astonished.' (Marianus 118,10: Mark 1.27)

A fourth group of verbs are those that are not attested in the relevant past tense forms, e.g. vlbsnoti 'blabber, stutter'. These verbs will be referred to as "irrelevant verbs", since they do not have a bearing on the discussion of the $n q /-\varnothing$ variation.

From modern Russian we know that whether a verb is prefixed or not has a bearing on the variation between the nasal suffix and $-\varnothing$ in the past tense (Nesset and Makarova 2011). Although less is known about aspectual prefixation in OCS, I will follow standard practice and treat unprefixed and prefixed verbs as "different verbs" in the following. Many verb roots combine with several prefixes. For instance, gybnoti 'perish' is attested with po- and iz-, dvignoti 'move' with $p o-$ and $v z z^{-}$, and szxnoti 'dry' with $u-, i z-$ and sz-. Since there is no indication that the choice of prefix affects the $-n q /-\emptyset$ variation, for the purposes of the present study I will regard all the prefixations of one verb root as "one verb" (for which I will use the following format: PREF-gybnoti, PREF-dvignoti, PREFszxneti etc.). Notice that this does not imply that I believe that prefixation is 
inflectional in OCS. Rather, the decision was made for methodological reasons. By grouping all prefixations of a root as one unit we are in a position to classify the units as $\emptyset$-verbs, vacillating verbs and nasal verbs with more certainty, since we have more examples per unit. Furthermore, a situation where each verb has more attestations makes statistical analysis easier and more reliable, which is of major importance for the present study.

Although in OCS there are quite a few verbs that combine with both $-n \varphi$ and $-\varnothing$ in the past tense, my database shows that in most cases one suffix is clearly dominant. A case in point is kosnoti 'touch'; while we have 29 attested aorists, only one displays the $-\emptyset$ suffix (the 3 sg aorist kose, Suprasliensis 561,28). Should this verb be classified as a "vacillating verb"? Since kosneti overwhelmingly favors $-n q$ over $-\emptyset$, this verb clearly has more in common with $\emptyset$-verbs than with a verb with, say, a fifty-fifty distribution of the two suffixes. For this reason, verbs where less than $10 \%$ of the examples have $-n g$ in the relevant past tense forms are regarded as $\varnothing$-verbs for the purposes of the present study. Conversely, verbs with less than $10 \%-\emptyset$ are classified as nasal verbs. In other words, vacillating verbs are those where the most frequent suffix covers less than $90 \%$ of the relevant past tense forms, while the least frequent suffix represents more than $10 \%$ of the forms in question. ${ }^{i i i}$

Complete lists of verbs are given in (13) through (16). The numbers in parentheses represent the total number of attested examples for each verb (i.e. their token frequency). Verbs with token frequency $\geq 10$ are given in boldface. As can be seen from (13), the database contains $34 \emptyset$-verbs, 16 of which are in the boldfaced, high frequency group. The total number of attested examples in the group is 666 .

(13) Ø-verbs: obyknoti (10) 'be accustomed to', PREF-běgnoti (42) 'run', PREFvyknoti (56) 'learn', uvęznoti (3) 'get entangled, be trapped', ugasnoti (4) 'go out, be quenched', uglbbnoti (2) 'be stuck in', pogręznoti (4) 'sink', gybnoti (4) 'die', PREF-gybnoti (117) 'perish', PREF-dvignoti (96) 'move', dvignoti (26) 'move', prozębnoti (24) 'come up, grow, sprout', zaklenoti (3) 'lock up', (sъ)vъskrbsnoti (108) 'be resurrected', PREF-kysnoti (4) 'turn sour', prilb(p)noti (10) 'cling, stick to', PREF-mrbznoti (4) 'freeze to ice', mrbknoti (8) 'get dark', PREF-mrbknoti (3) 'get dark; find self in dark; be late', PREF-mъknoti (6) 'penetrate', PREF-niknoti (19) 'bend', PREFnbznoti (PREF-nbsti) (13) 'attach to', poplbznoti (1) 'stumble', szręgnoti (1) 'marry', posagnoti (3) 'get/be married', prisvęnoti (3) 'wilt, fade', postignoti (17) 'reach', PREF-sęgnoti (4) 'touch', PREF-to(p)noti (10) 'drown, be shipwrecked', utrb(p)noti (1) 'become lame, stiffen', PREFtrknoti (32) 'push', PREF-tęgnoti (14) 'stretch out', oxrъmnoti (1) 'go lame', iščeznoti (ičeznoti) (13) 'disappear'.

The list of nasal verbs in (14) contains 31 verbs that are attested in a total of 448 examples. Eleven verbs display ten or more attestations.

(14) Nasal verbs: obinqti (3) 'avoid, shun', vъzbъnфti (1) 'wake up', povinoti (sę) (11) 'obey, be subject to', vyknoti (5) 'learn, get used to', uvęnoti (2) 'wilt', PREF-grnoti (7) 'bend', PREF-dunoti (4) 'blow', dunqti (4) 'blow', drbznoti (31) 'take courage, be bold', zinoti (2) 'yawn', kanqti (1) 'drip', vъskliknoti 
(10) 'cry out, exult', kosnoti (43) 'touch', prikosnoti (se) (70) 'touch', nakynoti (1) 'nod to', pomanoti (8) 'beckon, wave at, nod to', minoti (10) 'pass by', PREF-minoti (3) 'pass by', poměnoti (65) 'remember', (vъs)pomęnoti (82) 'remember', umęknoti (1) 'get soft', plinoti (11) 'spit', vъspljunoti (2) 'spit', pljunoti (3) 'spit', vъspręnoti (3) 'get up', PREF-rinoti (32) 'push', rinoti (1) 'push', otъrygnoti (otzrignnoti) (4) 'erupt', PREFsěknoti (18) 'cut off, behead', tlbknoti (8) 'knock', ţ knoti (2) 'strike, pierce, wound'.

The group of vacillating verbs is smaller. As can be seen from (15), it comprises nine verbs, seven of which are in the high-frequent boldfaced group. The total number of attested examples in this group is 225 .

(15) Vacillating verbs: goneznoti (10) 'avoid', PREF-dzxnoti (26) 'breathe', užasnoti sę (28) 'be astonished', PREF-mlbknoti (8) 'fall silent', oslbpnoti (5) 'go blind', usъnoti (50) 'fall asleep', PREF-sъxnoti (29) 'dry', isęknoti (12) 'dry up', PREF-trъgnoti (45) 'tear'.

Irrelevant verbs are the smallest group; as shown in (16) this group consists of four verbs, each of which is attested only once:

(16) Irrelevant verbs: vlısnoti (1) 'blabber, stutter', vъsplanoti (1) 'flare up', isunoti (1) 'pull out', szxnoti (1) 'dry'.

\section{Grammatical profiles}

With the classification from the previous section in mind, we are now in a position to test the hypotheses from section 2. Do Ø-verbs, nasal verbs and vacillating verbs show uniform or diverse behavior? In order to find out, I will apply linguistic profiling - a suite of methodologies in cognitive linguistics inspired by Stefanowitsch and Gries' (2003) pioneering work on "collostructional analysis" and Divjak and Gries' (2006) work on "behavioral profiles". The basic idea of linguistic profiling is to tease apart subtle differences between linguistic elements based on their behavior in corpora (cf. e.g. Janda and Solovyev 2009, Janda and Lyashevskaya 2011 and submitted, Nesset, Endresen and Janda 2011). One member of the linguistic profiling family is the grammatical profile, which will be employed in this section. Janda and Lyashevskaya $(2011,719)$ define a grammatical profile as the "relative frequency distribution of the inflected forms of a word in a corpus". The basic observation is that words show different frequencies of use in different cells of the inflectional paradigm. Some verbs may occur frequently in the past tense, while others are more frequently used in other cells in the paradigm, say, the present tense or the imperative. Such verbs have different grammatical profiles. Janda and Lyashevskaya (2011) use grammatical profiles to investigate two types of aspectual pairs in Contemporary Standard Russian, and Eckhoff and Janda (forthcoming) explore the category of aspect in OCS verbs by means of grammatical profiles. The methodology has two steps. First, one establishes the corpus frequencies of the classes of words under scrutiny, and then the observed differences are analyzed statistically in order to find out if they are statistically significant and what their effect size is. 
In establishing the grammatical profiles of $\emptyset$-verbs, nasal verbs and vacillating verbs, the limited size of the database under scrutiny poses a challenge, since grammatical profiles are more accurate and representative when they are based on a larger amount of data for each given verb. Eckhoff and Janda (forthcoming) explain this as follows: "if we have 100 attestations for a given verb, it is meaningful to say that the verb occurs $20 \%$ of the time in the aorist form, $3 \%$ in the imperfect, etc. If, however, we have only three attestations of a verb and all of them are aorist forms, it is not as meaningful to say that this verb occurs $100 \%$ in aorist and $0 \%$ in imperfect since we have so little data and it could be the case that the three examples just happen to be aorist forms. Rare verbs thus pose a risk for misrepresenting the data and need to be eliminated." The lower the frequency of the verb, the less certain is its classification as $\emptyset$-verb, nasal verb or vacillating verb. By excluding low-frequency verbs from the investigation we reduce this problem. Janda and Lyashevskaya (2011), who worked with a 92 million word corpus, set the frequency threshold to 100, while Eckhoff and Janda (forthcoming) investigated 15,000 word corpus and set the threshold to 20 . Since the present study is based on an even smaller dataset, the threshold is set to 10 attestations. In other words, for the purposes of the discussion of grammatical profiles I will only include the verbs given in boldface in (13) to (16).

The three hypotheses discussed in section 2 make different predictions. If all OCS $n q$-verbs constitute one category, as assumed in the one-category hypothesis, we expect $\emptyset$-verbs, nasal verbs and vacillating verbs to have identical or, at least, very similar grammatical profiles. The multi-category hypothesis, on the other hand, predicts substantial differences in the grammatical profiles of the three classes of $n q$-verbs, while the network hypothesis leads us to expect smaller differences.

Table 2 and Figure 1 summarize the situation. The leftmost column includes nine groups of inflectional forms; in view of the limited size of the database, it is not possible to give a more fine-grained analysis of, say, the differences between singular and plural forms of aorists or different case forms of participles. In fact, present participles, imperfect, the resultative L-participle and the past passive participle display such low frequencies for all groups of verbs that they could not be included in statistical analysis of the grammatical profiles. These forms are therefore also not represented in Figure 1, which visualizes the situation. The columns for $\emptyset$-verbs, nasal verbs and vacillating verbs in Table 2 give raw numbers and percentages for each class, while the rightmost column offers total numbers. As can be seen from Table 2 and Figure 1, there are both similarities and differences among the three classes of verbs. All classes are well attested in the aorist; for $\varnothing$-verbs this is the second most frequent form, while for nasal verbs and vacillating verbs it is the most frequent form. Important differences concern the present tense and past active participles. These forms show high relative frequencies for $\emptyset$-verbs, but are less frequent in nasal verbs and vacillating verbs. Statistical analysis indicates that the differences between the grammatical profiles of $\emptyset$-verbs, nasal verbs and vacillating verbs are highly significant, and that the effect size is moderate.iv The robust differences are at variance with the one-category hypothesis, which predicts uniform behavior across $\emptyset$-verbs, nasal verbs and vacillating verbs. The fact that the differences 
are highly significant is compatible with both the multi-category and network hypotheses. The moderate effect size suggests that the differences are not dramatic, as predicted by the network hypothesis. However, further tests are required before more definite conclusions can be drawn. In the following section, we turn to another test in the linguistic profiling family, namely radial category profiling.

\begin{tabular}{lrrrrrrr} 
& \multicolumn{2}{c}{$\emptyset$-verbs: } & \multicolumn{2}{c}{ Nasal verbs: } & \multicolumn{2}{c}{ Vacillating verbs: } & Total: \\
& $\#$ & $\%$ & $\#$ & $\%$ & $\#$ & $\%$ & \\
\hline Present & 174 & 29 & 57 & 15 & 31 & 16 & 262 \\
Pres participles & 2 & 0 & 1 & 0 & 1 & 1 & 4 \\
Imperative & 62 & 10 & 77 & 20 & 6 & 3 & 145 \\
Infinitive & 47 & 8 & 18 & 5 & 14 & 7 & 79 \\
Imperfect & 2 & 0 & 0 & 0 & 2 & 1 & 4 \\
Aorist & 165 & 27 & 171 & 45 & 100 & 50 & 436 \\
Past act part & 124 & 20 & 40 & 10 & 43 & 22 & 207 \\
L-participle & 20 & 3 & 9 & 2 & 1 & 1 & 30 \\
Past pass part & 11 & 2 & 10 & 3 & 2 & 1 & 23 \\
\hline Total & 607 & 100 & 383 & 100 & 200 & 100 & 1190
\end{tabular}

Table 2: Grammatical profiles of OCS no-verbs

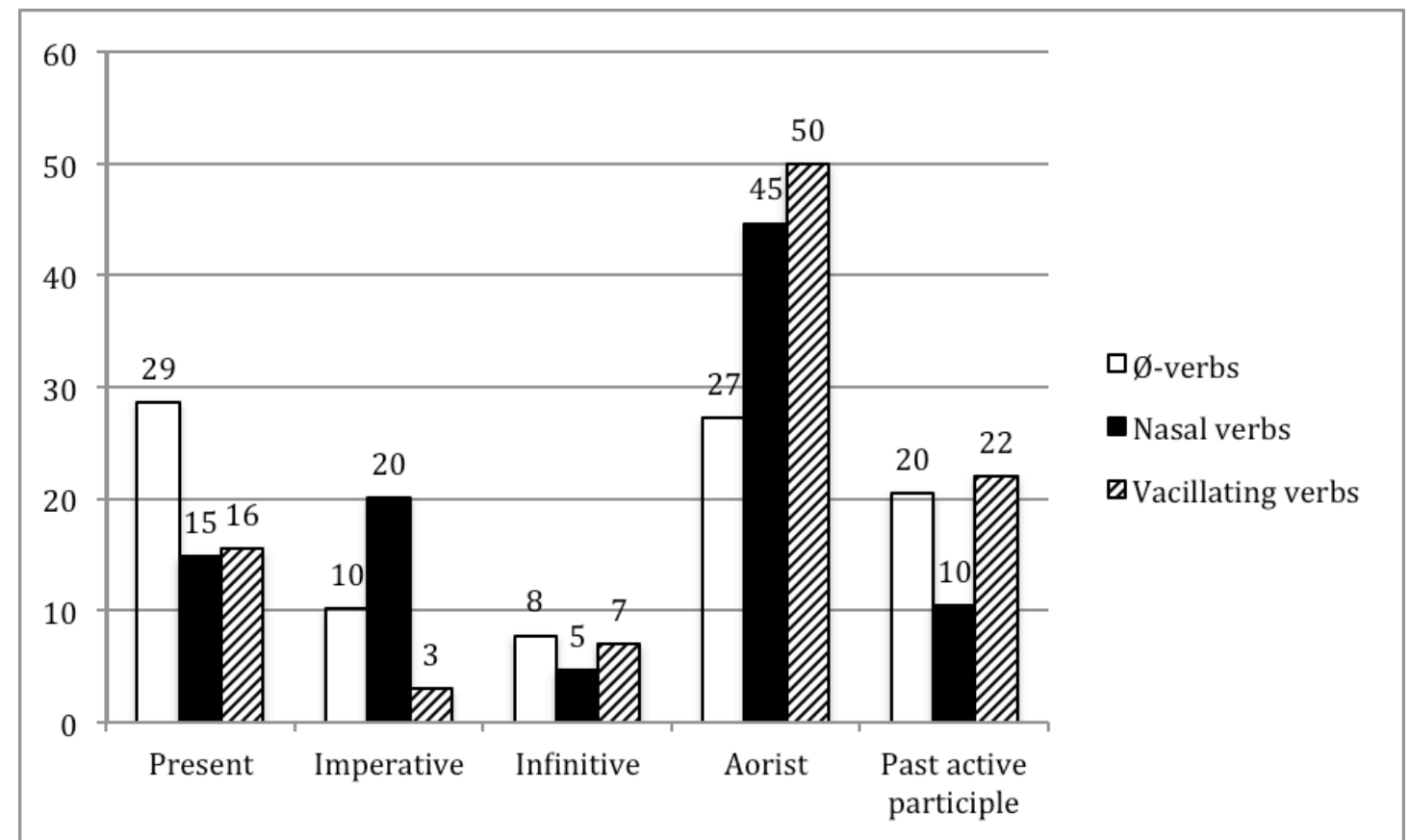

Figure 1: Grammatical profiles of OCS no-verbs (percentages from Table 2)

\section{Semantic differences: radial category profiling}

The radial category is one of the cornerstones of cognitive linguistics. As mentioned in section 3, the idea is that linguistic categories form networks of related subcategories that are organized around one or several prototypes. Radial category profiles (introduced by Nesset, Endresen and Janda 2011) take the radial category as the point of departure for quantitative analysis; a Radial Category Profile is the relative frequency distribution of the subcategories of a radial category (Nesset, Endresen and Janda 2011, 397). The method entails two steps. First, one establishes a network of related subcategories and assigns all 
the relevant words to subcategories. Second, the frequencies of the subcategories are compared by means of statistical analysis.

Although different scholars adopt different classifications, it is uncontroversial that the OCS no-verbs are semantically diverse (cf. e.g. Stang 1942, 56-58, Dostál 1954, 100f. et passim, Vaillant 1966, 234 et passim, Gorbachov 2007, 62 et passim). For present purposes, it is sufficient to distinguish between four semantic groups (some of which have subgroups). We shall see that these groups differ with regard to agentivity and embodiment, but that they are not unrelated, insofar as they constitute a so-called family resemblance chain.

The first semantic group comprises volitional actions performed by an agentive subject who moves a body part in order to carry out the action. In some cases, the agentive subject uses an instrument (e.g. usěknoti 'behead'), but in the majority of verbs no instrument is required (e.g. kosnoti 'touch'). Verbs in this group are typically transitive. A closely related group is verbs of motion, such as izběgnoti 'run away from, flee, escape'. Although verbs of motion resemble bodily acts in that both groups involve the body, motion verbs imply a change of location, while bodily acts do not. Notice that the attested examples of motion verbs with -no in OCS mostly denote motion away from something (e.g. -běgnoti in combination with prefixes $i z^{-}, \mathrm{raz}_{-}, \mathrm{otz}_{-}$and $u^{-}$), and that the motion verbs are used about metaphorical movement away, i.e. in the meaning 'avoid'. A case in point is goneznoti 'avoid'. $\mathrm{v}$ The metaphorical uses relate the verbs of motion to the third semantic group, for which I will use the label "cognitive verbs". This group contains verbs designating cognitive processes such as memory (e.g. pomęnoti 'remember') and surprise (užasnoti sę 'be astonished'), and I also include vlъsnoti 'blabber, stutter' and vъskliknotii 'cry out, exult' since these verbs reflect mental states.

While bodily acts such as usěknoti 'behead' are clearly agentive, motion verbs are less obviously agentive, especially in the metaphorical meaning 'avoid'; fleeing, escaping and avoiding tend to represent sudden responses to an external threat rather than carefully planned volitional actions. Even less clearly agentive are the cognitive verbs, which typically denote mental processes that a person undergoes. To be astonished, for example, is not an action you can plan and carry out volitionally, but rather something that is beyond control. The fourth semantic group of OCS no-verbs, for which I will use the traditional label "inchoative", is the most clearly non-agentive; the subjects of verbs like pogybnoti 'perish' and prozębnoti 'come up, grow, sprout' are passive undergoers (patients), not volitional agents. ${ }^{\mathrm{vi}}$ Unprefixed verbs in the inchoative group denote a process leading up to a change of state, while prefixed verbs describe the change of state itself. For instance, unprefixed szxnoti 'become dry' may denote a gradual reduction of humidity, whereas prefixed is $3 x n q t i$ 'dry out' describes the transition from wet to dry. Some of the inchoative verbs resemble bodily acts and motion verbs in that they describe processes that affect the human body. A case in point is pogybnoti 'perish'. Other inchoative verbs such as prozębnoti 'come up, grow, sprout' refer to processes in nature that do not directly concern the human body.

We have now seen that the semantic groups of verbs differ with regard to agentivity (whether they have an agentive subject or not) and embodiment 
(whether they concern the human body or not). Agentivity and embodiment are in principle independent of each other, so it is possible to place the verb groups in a two-dimensional semantic space defined by these variables. In Figure 2, the horizontal axis represents agentivity, and the vertical axis embodiment. Bodily acts are high on both embodiment and agentivity, and are therefore located in the upper right portion of the figure. Diametrically opposed to the bodily acts is the subgroup of inchoatives that are not concerned with the human body (nonembodied inchoatives). These inchoatives display minimal embodiment and agentivity, and are accordingly placed in the lower left portion of the figure. The remaining semantic groups are intermediate between these extremes. Motion verbs are embodied, but arguably less agentive than bodily acts. The cognitive verbs are lower on both agentivity and embodiment (they concern the mind, not the body), while the embodied inchoatives like pogybnoti 'perish' are high on embodiment, but are not agentive.



Figure 2: Agentivity and embodiment in OCS no-verbs

Figure 2 visualizes the differences between the semantic groups of OCS $n q$-verbs, but at the same time captures their similarities. I argue that we are dealing with a family resemblance chain, i.e. a chain where A resembles B and B resembles $C$, although $A$ and $C$ do not resemble each other (Taylor 2003). Non-embodied inchoatives like prozębnoti 'come up, grow, sprout' resemble embodied inchoatives like pogybnoti 'perish', which in turn resemble cognitive verbs, verbs of motion and bodily acts. It is important to keep in mind that each semantic group is not a point that has an exact location in the two-dimensional space depicted in Figure 2. Instead the groups occupy larger areas without clear-cut boundaries (represented as circles with dashed lines). We have seen that there is some variation within each group (e.g. in the case of non-metaphorical and metaphorical uses of motion verbs), and in some cases one and the same verb root displays very different behavior in combination with different prefixes. By way of example, consider the verbs vzzdrxnoti 'sigh' and izdrxnoti 'exhale, die' which share the same root. While the former is in the borderline area between bodily acts and cognitive verbs, the latter can be classified as an embodied inchoative when it is used about dying.

How are $\emptyset$-verbs, nasal verbs and vacillating verbs distributed across the semantic classes? Although unequivocal classification in some cases is not 
feasible, the classification in (17) through (20) is sufficiently precise for present

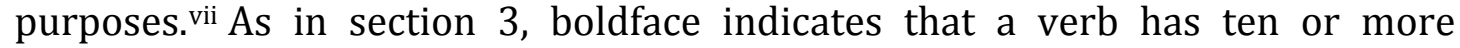
attestations. The numbers in parentheses provide the exact number of attestations for each verb.

(17) Bodily acts

a. Ø-verbs: PREF-dvignoti (96) 'move', dvignoti (26) 'move', zaklenoti (3) 'lock up', PREF-mъknoti (6) 'penetrate', PREF-niknoti (19) 'bend', PREF-nbznoti (PREF-nbsti) (13) 'attach to', PREF-seggnoti (4) 'touch', PREF-tъknoti (32) 'push, hit'viii, PREF-tęgnoti (14) 'stretch out'.

b. Nasal verbs: PREF-gъnoti (7) 'bend', PREF-dunoti (4) 'blow', dunqti (4) 'blow', zinoti (2) 'yawn', kosnoti (43) 'touch', prikosnoti (sę) (70) 'touch', nakynoti (1) 'nod to', pomanoti (8) 'beckon, wave at, nod to', plinoti (11) 'spit', vъspljunoti (2) 'spit', pljunoti (3) 'spit', vъspręnoti (3) 'get up', PREF-rinoti (32) 'push', rinoti (1) 'push', otъrygnoti (oţrignoti) (4) 'erupt', PREF-sěknoti (18) 'cut off, behead', tlbknoti (8) 'knock', tъknoti (2) 'strike, pierce, wound'.

c. Vacillating verbs: PREF-drxnoti (18) 'breathe'ix, PREF-trъgnoti (45) 'tear'.

(18) Verbs of motion

a. Ø-verbs: PREF-běgnoti (42) 'run', postignoti (17) 'reach'.

b. Nasal verbs: obinoti (3) 'avoid, shun', minqti (10) 'pass by', PREFminoti (3) 'pass by'.

c. Vacillating verbs: goneznoti (10) 'avoid'.

(19) Cognitive verbs

a. Ø-verbs: obyknoti (10) 'be accustomed to', PREF-vyknoti (56) 'learn'.

b. Nasal verbs: vyknoti (5) 'learn, get used to', drbznoti (31) 'take courage, be bold', poměnoti (65) 'remember', (vъs)pomęnoti (82) 'remember', vъskliknoti (10) 'cry out, exult'.

c. Vacillating verbs: užasnoti sę (28) 'be astonished'.

(20) Inchoative verbs

a. Ø-verbs: uvęznoti (3) 'get entangled, be trapped', uglbbnoti (2) 'be stuck in', pogręznoti (4) 'sink', gybnoti (4) 'die', PREF-gybnoti (117) 'perish', (sъ)vъskrbsnoti (108) 'be resurrected', prilb(p)noti (10) 'cling, stick to', poplbznoti (1) 'stumble', szpręgnoti (1) 'get married', PREFto(p)noti (10) 'drown, be shipwrecked', utrb(p)noti (1) 'become lame, stiffen', oxrъmnoti (1) 'go lame', ugasnoti (4) 'go out, be quenched', prozębnoti (24) 'come up, grow, sprout', PREF-kysnoti (4) 'turn sour', PREF-mrbznoti (4) 'freeze to ice', mrbknoti (8) 'get dark', PREF- 
mrbknoti (3) 'get dark; find self in dark; be late', prisvęnoti (3) 'wilt, fade', iščeznoti (ičeznoti) (13) 'disappear'.

b. Nasal verbs: vъzbъnoti (1) 'wake up', uvęnqti (2) 'wilt', umęknǫti (1) 'get soft'.

c. Vacillating verbs: izdzxnoti (8) 'exhale, die', PREF-şxnoti (29) 'dry out', isęknoti (12) 'dry up', PREF-mlbknoti (8) 'fall silent', oslbpnoti (5) 'go blind', usъnoti (50) 'fall asleep'.

On the basis of the classification in (17)-(20), we are now in a position to establish radial category profiles for $\emptyset$-verbs, nasal verbs and vacillating verbs. Tables 3 and 4 provide an overview of the situation. In Table 3, type frequencies (numbers of verbs) are given, while Table 4 offers token frequencies (numbers of examples). The tables give numbers for all verbs, and numbers for verbs with ten or more examples in italics. Figure 3 visualizes the situation for token frequencies (verbs with ten or more attestations), giving the frequencies in percent in order to put them on the same scale. The following observations can be made. Nasal verbs are most frequent in the category of bodily acts and cognitive verbs; bodily acts cover the highest number of verbs, but since several are of low frequency, cognitive verbs, which represent fewer, but more frequent verbs are the largest category of nasal verbs measured in token frequency. For $\emptyset$ verbs the most frequent subcategory is that of inchoative verbs; this applies to token frequencies, and also to type frequencies if low-frequent verbs are counted. Vacillating verbs resemble $\emptyset$-verbs in displaying high frequencies for inchoatives. In view of this, the following picture emerges. Nasal verbs have their center of gravity in the semantic category of bodily acts, while the prototype of $\emptyset$-verbs and vacillating verbs is inchoative verbs. In other words, there is an opposition between nasal verbs (which are high on agentivity and embodiment) and $\varnothing$-verbs/vacillating verbs (which tend to be low on agentivity and embodiment). However, we are not dealing with clear-cut boundaries, since there exist $\emptyset$-verbs and vacillating verbs among the bodily acts and - to a much lesser extent - nasal verbs among the inchoative verbs. In this way, the radial category profiles are in accordance with the network hypothesis.

The type frequencies reported in Table 3 are too small to be suitable for statistical analysis, but statistical analysis of the numbers in Table 4 is possible. Since there is good correspondence between type and token frequencies, a statistical comparison of token frequencies provides a good picture of the situation as a whole. As pointed out in section 3, the classification of lowfrequent verbs involves uncertainty, and therefore statistical analysis was carried out based on the token frequencies for verbs with ten or more attestations, i.e. the numbers given in italics in Table 4. The analysis shows that the differences between the radial category profiles are statistically highly significant and that the effect size is large. ${ }^{x}$ This lends further support to the network hypothesis; although nasal verbs, vacillating verbs and $\emptyset$-verbs are related through a family resemblance chain in a two-dimensional semantic space, the differences between their radial category profiles are nevertheless robust. 


\begin{tabular}{|c|c|c|c|c|c|c|c|c|}
\hline & \multicolumn{2}{|c|}{$\emptyset$-verbs } & \multicolumn{2}{|c|}{ Nasal verbs } & \multicolumn{2}{|c|}{$\begin{array}{c}\text { Vacillating } \\
\text { verbs }\end{array}$} & \multicolumn{2}{|c|}{ Total } \\
\hline Bodily acts & 9 & 6 & 18 & 5 & 2 & 2 & 28 & 13 \\
\hline Motion verbs & 2 & 2 & 3 & 1 & 1 & 1 & 7 & 4 \\
\hline Cognitive verbs & 2 & 2 & 5 & 4 & 1 & 1 & 8 & 7 \\
\hline Inchoative verbs & 20 & 6 & 3 & 0 & 8 & 3 & 31 & 9 \\
\hline Total & 32 & 15 & 29 & 10 & 12 & 7 & 74 & 33 \\
\hline
\end{tabular}

Table 3: Numbers of verbs (types; numbers for verbs with frequency $\geq 10$ given in italics)

\begin{tabular}{lrrrrrrrr} 
& \multicolumn{2}{c}{$\emptyset$-verbs } & \multicolumn{3}{c}{ Nasal verbs } & \multicolumn{2}{c}{$\begin{array}{c}\text { Vacillating } \\
\text { verbs }\end{array}$} & \multicolumn{2}{c}{ Total } \\
\hline Bodily acts & 213 & 200 & 223 & 174 & 63 & 63 & 497 & 437 \\
Motion verbs & 59 & 59 & 16 & 10 & 10 & 10 & 87 & 79 \\
Cognitive verbs & 66 & 66 & 193 & 187 & 28 & 28 & 287 & 281 \\
Inchoative verbs & 325 & 282 & 4 & 0 & 125 & 91 & 454 & 373 \\
Total & 663 & 607 & 436 & 371 & 226 & 192 & 1325 & 1170
\end{tabular}

Table 4: Numbers of examples (tokens; numbers for verbs with frequency $\geq 10$ given in italics)

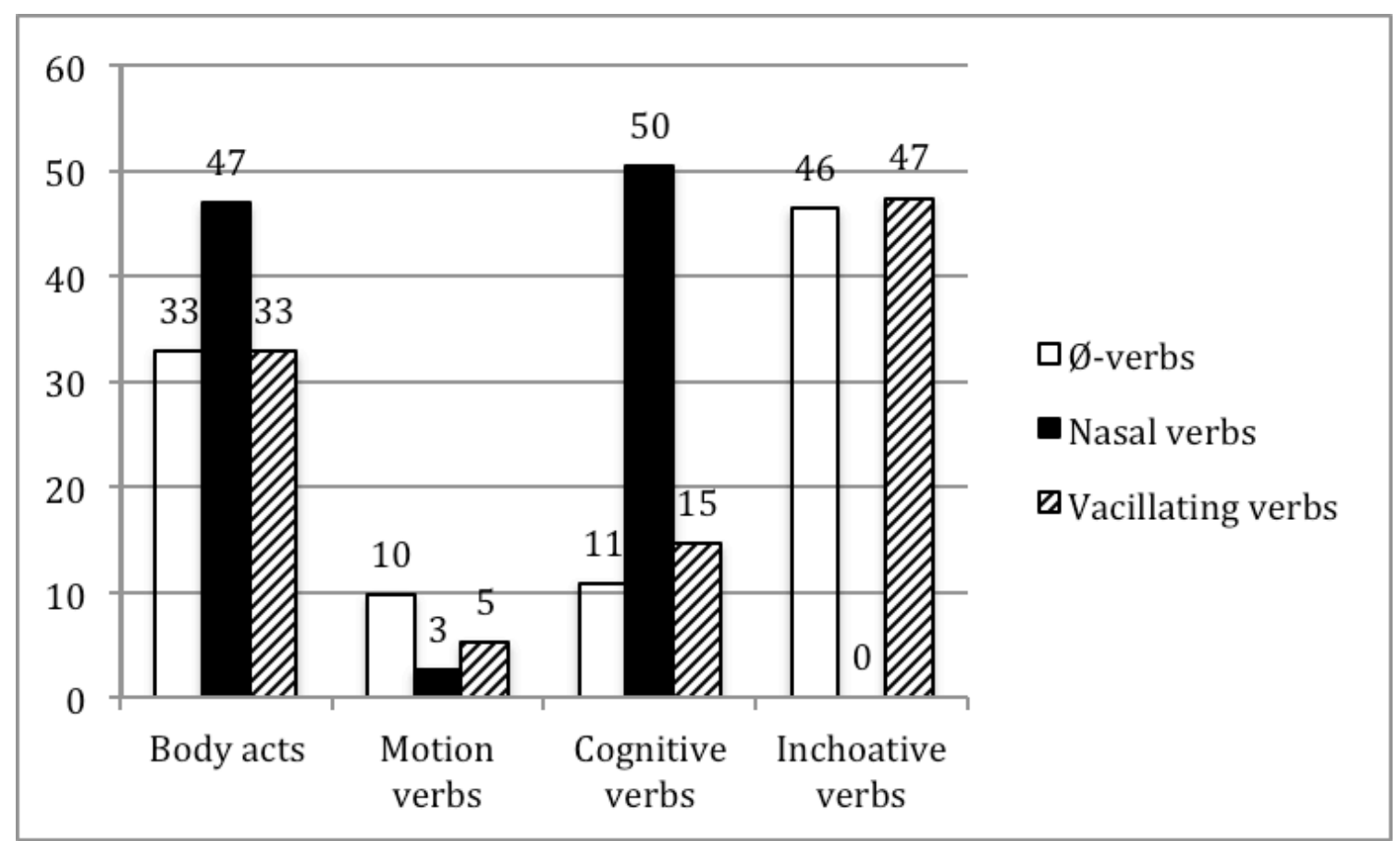

Figure 3: Radial category profiles (percent, based on high frequency verbs in Table 4)

\section{Formal differences: prefixation}

The difference between prefixed and unprefixed verbs has been shown to be relevant for nasal- $\varnothing$ variation in modern Russian (Nesset and Makarova 2011, 51-54), and in this section we will see that the same holds for OCS nq-verbs. However, once again we are not dealing with discrete, categorical differences, but rather statistical tendencies, as predicted by the network hypothesis.

Tables 5 and 6 provide an overview of the distribution of prefixed and unprefixed verbs among $\emptyset$-verbs, nasal verbs and vacillating verbs. Table 5 gives type frequencies (numbers of verbs), while token frequencies (numbers of 
examples) are given in Table 6. The numbers in italics concern verbs with at least ten attested examples. The tables show that unprefixed verbs are rare among OCS no-verbs as a whole. In terms of type frequency, only 16 out of $74 n q$ verbs lack a prefix ( 6 out of 34 for high-frequent verbs). Token frequencies offer a similar picture, insofar as only 169 out of 1310 examples are unprefixed (131 out of 1173 for high-frequent verbs). This being said, however, there are clear differences among the three types of verbs; unprefixed verbs are more frequent among nasal verbs than among $\varnothing$-verbs and vacillating verbs. For instance, 12 out of 31 nasal verbs are unprefixed ( 4 out of 11 if only high-frequent verbs are counted), while the corresponding numbers for $\emptyset$-verbs are 3 out of 34 ( 1 out of 16 for high-frequent verbs). Token frequencies reveal a similar picture: Out of 448 examples of nasal verbs 121 are unprefixed (95 out of 383 examples of highfrequent verbs), while for $\emptyset$-verbs only 38 out of 666 examples involve unprefixed verbs (26 out of 607 examples of high-frequent verbs). Although numbers in Table 5 are too small to facilitate reliable statistical analysis, it is possible to analyze the token frequencies in Table 6 statistically. The analysis of the token frequencies of high-frequent verbs, which is the most reliable source of information, shows that the observed differences are statistically highly significant and that the effect size is moderate. ${ }^{x i}$ In other words, there are robust differences between $\emptyset$-verbs, nasal verbs and vacillating verbs with regard to prefixation. This is at variance with the one-category hypothesis, which predicts uniform behavior across the three types of verb. Since we are dealing with statistical tendencies rather than categorical differences, the results favor the network hypothesis over the multi-category hypothesis.

\begin{tabular}{lcccccccr} 
& $\varnothing$-verbs & \multicolumn{3}{c}{ Nasal verbs } & \multicolumn{3}{c}{ Vacillating verbs } & \multicolumn{2}{c}{ Total } \\
\hline Unprefixed & 3 & 1 & 12 & 4 & 1 & 1 & 16 & 6 \\
Prefixed & 31 & 15 & 19 & 7 & 8 & 6 & 58 & 28 \\
Total & 34 & 16 & 31 & 11 & 9 & 7 & 74 & 34
\end{tabular}

Table 5: Numbers of verbs (types; numbers for verbs with frequency $\geq 10$ given in italics)

\begin{tabular}{lrrrrrrrr} 
& $\varnothing$-verbs & \multicolumn{3}{c}{ Nasal verbs } & \multicolumn{3}{c}{ Vacillating verbs } & \multicolumn{2}{c}{ Total } \\
\hline Unprefixed & 38 & 26 & 121 & 95 & 10 & 10 & 169 & 131 \\
Prefixed & 628 & 581 & 327 & 288 & 186 & 173 & 1141 & 1042 \\
Total & 666 & 607 & 448 & 383 & 196 & 183 & 1310 & 1173
\end{tabular}

Table 6: Numbers of examples (tokens; numbers for verbs with frequency $\geq 10$ given in italics)

\section{More formal differences: root-final segments}

One thing that all OCS handbooks and grammars agree on is that verbs with consonants and vowels in root-final position behave differently with regard to nasal- $\varnothing$ variation (cf. e.g. Leskien 1922, Diels 1963, Lunt 2001). In this section, we shall see that different consonants also play a role.

Classifying OCS nq-verbs with regard to the root-final segment is not trivial, because of ongoing phonological change in Common Slavic, whereby consonant clusters were simplified. According to Shevelov (1965, 193-196) labial and dental stops disappeared before a nasal consonant. This leads us to expect only the velars /k, g, x/ in front of /no/, but in OCS there are attested examples of labials before /no/, cf. e.g. pogybnoti 'perish'. As pointed out by Shevelov (1965, 
193) such examples are likely to be due to analogy, since the root-final consonant was not affected by sound change in related verbs such as pogybati 'perish'. In my database, the following verbs vacillate between a vowel and a consonant in root-final position: zaklenoti 'lock up' (but 3 sg aorist zaklepe), PREFtonoti 'drown, be shipwrecked' (but 3 sg aorist istope), prisvęnoti 'wilt, fade' (but 3 sg aorist prisvęde) and usъnoti 'fall asleep' (but 3 sg aorist usъpe). Should the roots of these verbs be classified as vowel-final or consonant-final? Since the nasal- $\varnothing$ variation under scrutiny in the present study occurs in the past tense, classification is based on these forms. In the relevant forms of zaklenoti, PREFtonoti and prisvęnoti we have attested examples only with consonants in rootfinal position, so for the purposes of the present study these verbs will be classified as consonant-final. For usznoti the situation is more complex; in addition to past tense forms with a consonant-final root followed by a $\emptyset$-suffix (e.g. 3 sg aorist uszpe) there are also examples with vowel-final root followed by /no/ (e.g. 1 sg aorist usznoxz). In view of the fact that the root of usznoti cannot be unequivocally classified as consonant- or vowel-final, this verb will not be included in the discussion of root shape in this section.

With this in mind, consider Tables 7 and 8, which provide an overview of the relationship between root-final segments on the one hand and $\emptyset$-verbs, nasal verbs and vacillating verbs on the other. The tables, which are organized in the same way as the tables in the previous section, confirm the traditional insight that only nasal verbs can have a vowel-final root. At the same time, it is important to notice that it is not the case that all nasal verbs have a vowel-final root. A case in point is kosneti 'touch' which (almost) consistently maintains the nasal suffix in the relevant past tense forms - a fact that has led some researchers to assume that this and similar verbs belonged to the same class as the vowel-final roots from the earliest (Slavic) times (cf. e.g. Stang 1942, 55, Diels 1963, 258 and Gorbachov 2007, 41 for discussion).

In addition to confirming the importance of the difference between vowel- and consonant-final roots, Tables 7 and 8 show that different classes of consonants also matter. First, labial-final roots are not attested in nasal verbs. Second, dental-final roots, and especially velar-final roots, are characteristic of $\varnothing$-verbs. Since the picture is so clear for vowel-final and labial-final roots, statistical analysis is hardly required; however, it shows high statistical significance and a very large effect size. ${ }^{\mathrm{xii}}$

\begin{tabular}{lrrrrrrrr} 
& \multicolumn{1}{c}{$\varnothing$-verbs } & \multicolumn{3}{c}{ Nasal verbs } & \multicolumn{3}{c}{$\begin{array}{c}\text { Vacillating } \\
\text { verbs }\end{array}$} & \multicolumn{2}{c}{ Total } \\
\hline Velar-final & 15 & 9 & 7 & 2 & 5 & 4 & 27 & 15 \\
Dental-final & 10 & 3 & 3 & 3 & 2 & 2 & 15 & 8 \\
Labial-final & 9 & 4 & 0 & 0 & 1 & 0 & 10 & 4 \\
Vowel-final & 0 & 0 & 21 & 6 & 0 & 0 & 21 & 6 \\
Total & 34 & 16 & 31 & 11 & 8 & 6 & 73 & 33
\end{tabular}

Table 7: Numbers of verbs (types; numbers for verbs with frequency $\geq 10$ given in italics) 


\begin{tabular}{lrrrrrrrr} 
& \multicolumn{1}{c}{$\varnothing$-verbs } & \multicolumn{3}{c}{ Nasal verbs } & \multicolumn{3}{c}{ Vacillating verbs } & \multicolumn{2}{c}{ Total } \\
\hline Velar-final & 337 & 312 & 48 & 28 & 103 & 95 & 488 & 435 \\
Dental-final & 157 & 134 & 144 & 144 & 38 & 38 & 339 & 316 \\
Labial-final & 172 & 161 & 0 & 0 & 5 & 0 & 177 & 161 \\
Vowel-final & 0 & 0 & 256 & 211 & 0 & 0 & 256 & 211 \\
Total & 666 & 607 & 448 & 383 & 146 & 133 & 1260 & 1123
\end{tabular}

Table 8: Numbers of examples (tokens; numbers for verbs with frequency $\geq 10$ given in italics)

What does the discussion of root-final segments tell us about the three competing hypotheses under scrutiny in the present study? The highly significant differences documented in Tables 7 and 8 are at variance with the one-category hypothesis, which would predict uniform behavior across the board. The fact that V-final roots are incompatible with $\emptyset$-verbs and vacillating verbs, while labial-final roots are incompatible with nasal verbs may at first glance seem to favor the multi-category hypothesis. However, as we have seen, upon closer inspection the relationship between root-shape on the one hand and $\emptyset$-verbs, nasal verbs and vacillating verbs on the other turns out to be less straightforward. Indeed, as has been pointed out by Gorbachov $(2007,41 \mathrm{ff}$.), the traditional distinction of two subclasses of OCS nq-verbs, one with vowel-final roots and one with consonant-final roots (cf. e.g. Diels 1963, 256ff. and Lunt $2001,128 f f$.), does not do justice to the complexity of the situation. It appears that the network hypothesis is better equipped for dealing with the complexity. If we assume that $\emptyset$-verbs, nasal verbs and vacillating verbs populate a single network of related subcategories, but that they gravitate toward different prototypes, we expect substantial differences, but also similarities and overlapping distributions. These predictions are borne out by the facts about the shape of the root explored in this section.

\section{Concluding discussion}

This study has explored the category structure of OCS $n q$-verbs and demonstrated that there are significant differences between $\emptyset$-verbs, nasal verbs and vacillating verbs. In section 4 it was shown that the three verb types have different grammatical profiles, and in sections 5 through 7 we have seen that there are semantic and formal differences between the three types of verbs. Simplifying somewhat, we can say that a prototypical $\emptyset$-verb is low on agentivity and embodiment, is prefixed and has a velar or dental consonant in root-final position. Nasal verbs, on the other hand, tend to be high on agentivity and embodiment. Nasal verbs are attested somewhat more often without a prefix than $\emptyset$-verbs, and nasal verbs typically have a vowel-final root. Vacillating verbs tend to occupy an intermediate position between $\emptyset$-verbs and nasal verbs.

However, although the differences are substantial, the present study has also established that there are similarities between the three types of verbs. With regard to semantics, we have seen that they populate a two-dimensional space defined by agentivity and embodiment. The semantic subcategories within this semantic space (bodily acts, motion verbs, cognitive verbs and inchoatives) are related and constitute a family resemblance chain. Although $\emptyset$-verbs, nasal verbs and vacillating verbs gravitate toward different prototypes within the semantic 
space, we are not dealing with categorical differences; for instance, there are $\emptyset$ verbs that are high on agentivity and embodiment (e.g. dvignoti 'move') and nasal verbs that are at the opposite end of the semantic space (e.g. uvęnoti 'wilt'). The formal factors we have explored lend further support to this conclusion. While unprefixed verbs are more common among nasal verbs, prefixed verbs represent the normal case for all three types of verbs. Although velar-final roots are characteristic for $\emptyset$-verbs, there are nasal verbs with such roots too, e.g. vъskliknoti 'cry out, exult'.

What kind of model is best suited for capturing both differences and similarities between $\emptyset$-verbs, nasal verbs and vacillating verbs? We have considered three hypotheses. The one-category hypothesis that predicts uniform behavior across all $n q$-verbs accounts for similarities, but not for the systematic differences we have detected. Conversely, the multi-category hypothesis predicts systematically different behaviors and therefore accommodates the differences, but not the similarities. The network hypothesis represents a compromise that fares better. If we assume that the OCS no-verbs gravitate toward different prototypes in a network of related subcategories, we are able to account for both the differences and the similarities.

To what extent do the results obtained in the present study shed light on the situation in Common Slavic? Even if we assume that the OCS text corpus to some degree reflects the language of speech communities at different times and locations, the OCS texts clearly are not a representative sample. To take a pedestrian example, it is not a daring guess that the verb vъskrbsnoti 'be resurrected' is much more frequent in the OCS text corpus than in everyday speech at the time. In view of this we cannot automatically extend the conclusions drawn in this article to Common Slavic. However, the present study offers a methodology that can be applied to other (early) Slavic data. If investigations of texts from South, West and East Slavic display a similar picture, we may be in a position to draw more certain conclusions about the category structure of $n q$-verbs in Common Slavic. Such studies may furthermore shed light on the diachronic development of the Slavic no-verbs - did the various types of $n q$-verbs drift farther apart or is there evidence for converging developments? However, these questions are beyond the scope of the present study and must be left for future research.

While the present study focuses on data from one variety of Slavic, the proposed analysis has implications beyond Slavic. We have seen that cognitive linguistics' conception of linguistic categories as networks of related subcategories organized around one or several prototypes has proved to be a fruitful approach - also for linguistic varieties that are attested in a limited number of sources from earlier ages. In the same vein, the method of linguistic profiling has been shown to be a valuable tool in the study of category structure. However, further research is required in order to establish with more certainty the relevance of cognitive linguistics for historical linguistics.

\footnotetext{
${ }^{i}$ In order to make this article accessible for linguists with little background in statistics, details about statistical analysis will be reported in footnotes. The main statistic test employed in the present study is Pearson's Chi-squared test. This test yields a p-value that indicates statistical
} 
significance, i.e. the likelihood that the observed distribution is due to chance. The lower the pvalue, the more significant the result. However, it is important to note that even a highly significant result does not necessarily imply that a factor has a strong impact. Imagine, for instance, a diet that consistently reduces people's weight. In such a case, the p-value will be very low, but this does not mean that the effect of the diet is strong - in fact the observed weight differences can be both statistically significant and negligible in size at the same time. In order to rule out such situations, Cramer's V-value, which is a measure of effect size, is computed in all cases where Pearson's Chi-squared test indicates statistical significance (or, at least, is close to statistical significance). All statistical tests are carried out in the freely downloadable software package R. In the case of Table 1, Pearson's Chi-squared test (X-squared $=12.2398, \mathrm{df}=6$ ) gives $\mathrm{p}$-value $=0.06$, which indicates that there is $6 \%$ chance that the observed differences are due to chance. According to standard practice, $\mathrm{p}$-value $=0.05$ is regarded as the threshold for statistical significance, so the result in Table 1 is in the borderline area between significance and insignificance. Cramer's V-value $=0.1$. This indicates a small effect size; even though Cramer's Vvalue can theoretically vary between 0 and $1,0.5$ is considered high, while 0.3 represents a moderate value and 0.1 a low value (cf. King and Minium 2008:327-329).

ii Examples are cited in transliteration, and provided with an English translation. The source is cited in the same way as in Aitzetmüller (1977). In quotes from the Bible, book, chapter and verse are given for the convenience of the reader.

iii Of course, a more fine-grained analysis is conceivable, say, with five categories: "pure $\emptyset$-verbs", "predominantly $\emptyset$-verbs", "vacillating verbs", "predominantly nasal verbs" and "pure nasal verbs". This option was not chosen because of the limited size of the database. With limited data available too many categories would jeopardize statistical analysis.

iv Pearson's Chi-squared test ( $\mathrm{X}$-squared $=110.2786, \mathrm{df}=8$ ) gives $\mathrm{p}$-value $<2.2 \mathrm{e}-16$. This is the smallest number the software package $\mathrm{R}$ operates with $(0 \ldots 22$ with fifteen zeros before 22), so for all practical purposes the likelihood that the differences observed in Table 2 should be due to chance equals zero. Cramer's V-value $=0.3$, which indicates a moderate effect size.

$v$ It must be admitted that it is hard to pinpoint the exact meaning of this Gothic loanword, which is attested in Codex Suprasliensis, but not in the semantically more transparent Biblical texts. Lunt glosses goneznoti as 'avoid' (Lunt 1969) and 'be rid of' (Lunt 2001: 129), while Cejtlin et al. (1999) provide the Russian synonyms osvobodit'sja, spastis', izbavit'sja ot kogo-l./čego-l., izbežat' čego-l. and Sadnik and Aitzetmüller (1955) the following German equivalents: genesen, entgehen, sich retten, jem. verborgen sein. At least in examples of the following type, where goneznoti appears to be opposed to pričastiti sę 'join, become a participant in', goneznoti seems to involve a deliberate effort to avoid something, which I interpret as (metaphorical) movement away from something: ne xotęaše s nimi pričastiti sę nъ goneznouti ixъ xotja 'did not want to join them, but wished to avoid them'. On this basis I have decided to group goneznoti with motion verbs such as otzběgnoti and uběgnoti. The fact that goneznoti governs the genitive case lends further support to this analysis, since in the words of Lunt (2001: 145) genitive complements are characteristic of verbs "denoting deprivation and the like", e.g. izběgnoti 'avoid'.

vi For the purposes of the present paper I use the traditional term "inchoative", which is well established in Slavic linguistics (cf. e.g. Schuyt 1990). It should be pointed out that this is somewhat imprecise, insofar as verbs like sъxnoti 'become dry' and mrbknoti 'get dark' strictly speaking do not describe the beginning of a process. A possible alternative is "gradative" (Russian: gradativ, Padučeva 1996: 117).

vii Since assigning the stative posagnoti 'be married' and povinoti (se) 'obey, be subject to', as well as the activity verb kanoti 'drip' to the semantic groups in (17)-(20) is not straightforward, these verbs are left aside for the purposes of radial category profiles.

viii PREF-tzknoti 'push, hit' is classified as a bodily act, although in the combination with the reflexive particle se potzknoti is also used in the meaning 'stumble', which is close to motion verbs.

ix All prefixed verbs from dzxnoti are classified as bodily acts, except izdzxnoti which is used in the (metonymically related) meaning 'die' and therefore is classified as an inchoative verb in (20c).

x Pearson's Chi-squared test $(\mathrm{X}$-squared $=362.4751, \mathrm{df}=6)$ gives $\mathrm{p}$-value $<2.2 \mathrm{e}-16$. Cramer's Vvalue $=0.6$.

xi Pearson's Chi-squared test $(X-s q u a r e d=106.7875, \mathrm{df}=2$ ) gives $\mathrm{p}$-value $<2.2 \mathrm{e}-16$. Cramer's Vvalue $=0.3$. 
xii Pearson's Chi-squared test of the numbers in Table 8 for high-frequency verbs (the numbers in parentheses) gives p-value $<2.2 \mathrm{e}-16(\mathrm{X}$-squared $=724.1319, \mathrm{df}=6)$. Cramer's V-value $=0.8$.

\section{References}

Aitzetmüller, R.: 1977, Belegstellenverzeichnis der altkirchenslavischen Verbalformen, Würzburg.

Cejtlin, R.M., R. Večerka and È. Blagova: 1999, Staroslavjanskij slovar' (second ed.), Moscow.

Dickey, S.M. forthcoming, Verbal Aspect in Late Common Slavic. Ms, Kansas University.

Diels, P.: 1963, Altkirchenslavische Grammatik (second ed.), Heidelberg.

Divjak, D. and S.Th. Gries: 2006, 'Ways of trying in Russian: clustering behavioral profiles', Corpus Linguistics and Linguistic Theory 2.1, 23-60.

Dostál A.: 1954, Studie o vidovém systému v staroslověnštině. Prague.

Eckhoff, H.M. and L.A. Janda: forthcoming, 'Grammatical Profiles and Aspect in Old Church Slavonic'. Ms: Center for Advanced Study/University of Oslo/University of Tromsø.

Gorbachov, Ya.V.: 2007, Indo-European Origins of the Nasal Inchoative Class in Germanic, Baltic and Slavic. Doctoral dissertation: Harvard University.

Janda, L.A. and O.N. Lyashevskaya 2011, 'Grammatical profiles and the interaction of the lexicon with aspect, tense and mood in Russian', Cognitive Linguistics 22:4, 719-763.

Janda, L.A. and O.N. Lyashevskaya: submitted, 'Semantic Profiles of Five Russian Prefixes: $p o-, s-, z a-, n a-$, pro-', Ms. University of Troms $\varnothing$.

Janda, L.A. and V. Solovyev: 2009, 'What Constructional Profiles Reveal About Synonymy: A Case Study of Russian Words for SADNESS and HAPPINESS', Cognitive Linguistics 20.2, 367-393.

King, B.M. and E. Minium: 2008, Statistical Reasoning in the Behavioral Sciences, Hoboken, NJ.

Lakoff, G.: 1987, Women, Fire, and Dangerous Things, Chicago.

Leskien, A.: 1922, Handbuch der altbulgarischen (altkirchenslavischen) Sprache (sixth edition), Heidelberg.

Lunt, H.G.: 1969, Old Church Slavonic Glossary (corrected reprint), Cambridge, Mass.

Lunt, H.G.: 2001, Old Church Slavonic Grammar (seventh ed.), Berlin and New York.

Nesset, T., A. Endresen and L.A. Janda: 2011, 'Two ways of getting out: Radial Category Profiling and the Russian prefixes $v y$ - and iz-'. Accepted for publication in Zeitschrift für Slawistik 56.4, 377-402.

Nesset, T. and A. Makarova: 2011, "Nu-drop" in Russian verbs: a corpus-based investigation of morphological variation and change', Russian Linguistics 35.4, 41-63.

Padučeva, E.V.: 1996, Semantičeskie issledovanija, Moscow.

Plungian, V.A.: 2000, “Bystro' v grammatike russkogo i drugix jazykov', in Iomdin, L.L. and L.P. Krysin (eds.), Slovo v tekste i v slovare: sbornik statej $\mathrm{k}$ semidesjatiletiju akademika Ju. D. Apresjana, Moscow.

Sadnik, L. and R. Aitzetmüller: 1955, Handwörterbuch zu den altkircheslavischen Texten, The Hague. 
Schuyt, R.: 1990, The Morpholgy of Slavic Verbal Aspect. A Descriptive and Historical Study, Amsterdam/Atlanta GA.

Shevelov, G.Y.: 1965, A Prehistory of Slavic. The Historical Phonology of Common Slavic, New York.

Stang, C.S.: 1942, Das slavische und baltische Verbum, Oslo.

Stefanowitsch, A. and S.Th. Gries: 2003, 'Collostructions: Investigating the interaction between words and constructions', International Journal of Corpus Linguistics 8.2: 209-43.

Taylor, J.R.: 2003, Linguistic Categorization (third ed.), Oxford.

Vaillant, A.: 1966, Grammaire comparée des langues slaves 3, Paris. 